\title{
Evolution of Microstructure During the In Situ Heating of 42 Pct Cold-Rolled High Mn Steel
}

\author{
SUDIPTA PRAMANIK, DAVID R.G. MITCHELL, AHMED A. SALEH, \\ AZDIAR A. GAZDER, and ELENA V. PERELOMA
}

\begin{abstract}
An Fe-17Mn-3Al-2Si-1Ni-0.06C wt pct high $\mathrm{Mn}$ steel was cold rolled to 42 pct thickness reduction, leading to a mixed microstructure of $\varepsilon$ - and $\alpha^{\prime}$-martensite along with a trace amount of austenite $(\gamma)$. The reverse transformation of $\varepsilon$ - and $\alpha^{\prime}$-martensite to $\gamma$ was tracked by in situ heating from room temperature up to $800{ }^{\circ} \mathrm{C}$ followed by 600 seconds holding in a transmission electron microscope. The transformation of $\varepsilon$ - and $\alpha^{\prime}$-martensite to $\gamma$ followed the Shoji-Nishiyama (S-N) and Kurdjumov-Sachs $(\mathrm{K}-\mathrm{S})$ orientation relationships, respectively. No changes in the grain shape or motion of any interfaces between $\varepsilon$-martensite $/ \gamma$ and $\alpha^{\prime}$-martensite $/ \gamma$ were observed during the reverse transformation process. The $\gamma$ reverted from $\varepsilon$-martensite contained fine twins upon recovery, and a mechanism is proposed for the formation of these twins.
\end{abstract}

https://doi.org/10.1007/s11661-018-5011-7

(C) The Minerals, Metals \& Materials Society and ASM International 2018

\section{INTRODUCTION}

WEIGHT reduction of automobile bodies has become a global challenge in order to decrease fuel consumption and the emission of greenhouse gases. A potential candidate to meet this demand is high $\mathrm{Mn}$ transformation-induced plasticity (TRIP) steel due to its unique combination of high strength and ductility. ${ }^{[1,2]}$ Optimizing the final mechanical properties of high-Mn TRIP steels requires a comprehensive understanding of the microstructure evolution during post-deformation annealing treatments.

During cold deformation of TRIP steels, the initial metastable face-centered cubic (fcc) austenite $(\gamma)$ phase transforms to hexagonal close-packed (hcp) $\varepsilon$-martensite and/or body-centered cubic (bcc) $\alpha^{\prime}$-martensite. During subsequent heat treatments, the $\varepsilon^{-}$and $\alpha^{\prime}$-martensite revert to $\gamma$.

Upon heating, the shrinkage of $\varepsilon$-martensite stacking faults takes place first prior to the onset of $\varepsilon$-martensite reversion. ${ }^{[3]}$ The reversion of $\varepsilon$-martensite to $\gamma$ occurs by

SUDIPTA PRAMANIK and AHMED A. SALEH are with the School of Mechanical, Materials, Mechatronic and Biomedical Engineering, University of Wollongong, Wollongong, NSW 2522, Australia. Contact e-mail: sp345@uowmail.edu.au DAVID R.G. MITCHELL and AZDIAR A. GAZDER are with the Electron Microscopy Centre, AIIM, Innovation Campus, Squires Way, University of Wollongong, Wollongong, NSW 2500, Australia. ELENA V. PERELOMA is with the School of Mechanical, Materials, Mechatronic and Biomedical Engineering, University of Wollongong and also with the Electron Microscopy Centre, AIIM, Innovation Campus.

Manuscript submitted April 11, 2018.

Article published online November 19, 2018 a displacive transformation mechanism, where the reverted $\gamma$ grain inherits the same shape as the parent $\varepsilon$-martensite grain. The reversion starts both within and outside of the parent $\varepsilon$-martensite grain leading to the formation of a thin $\gamma / \varepsilon$-martensite lamellar structure. ${ }^{[3]}$ Also during displacive reversion, the $\varepsilon$-martensite start temperature was found to be independent of the heating rate during annealing. ${ }^{[4]}$ The operation of ShojiNishiyama $(\mathrm{S}-\mathrm{N})$ orientation relationship (OR, $\left.(111)_{\gamma}\left\|(0001)_{\varepsilon},[1 \overline{1} 0]_{\gamma}\right\|[11 \overline{2} 0]_{\varepsilon}\right)$ is followed between $\gamma$ and $\varepsilon$-martensite during reversion. ${ }^{[5]}$

The reversion of $\alpha^{\prime}$-martensite to $\gamma$ can proceed via a displacive or diffusional transformation mechanism. ${ }^{[6]}$ The displacive transformation occurs via the shear reversion of $\alpha^{\prime}$-martensite which leads to the formation of reverted $\gamma$ laths inheriting the morphology of the parent $\alpha^{\prime}$-martensite, and which contain a high density of dislocations. With further increase in the annealing temperature or time, the boundaries between the $\gamma$ laths disappear, and the inherited lath structure transforms to a blocky morphology which is bounded by high-angle grain boundaries. ${ }^{[6]}$ Thus, the grain size of the reverted $\gamma$ is equal to the size of the $\gamma$ blocks.

Upon further annealing, the recovery and recrystallization of the reverted $\gamma$ formed by displacive $\alpha^{\prime}$-martensite reversion takes place. The dislocations in the reverted $\gamma$ blocks form a cellular structure which changes to subgrains during recovery. The subgrains coalesce via lattice rotation or subgrain boundary migration to form the recrystallized $\gamma$ grains which are finer in size compared to the reverted $\gamma$ blocks. ${ }^{[6,7]}$ 
Alternatively, the diffusional $\alpha^{\prime}$-martensite reversion occurs by the random nucleation of reverted $\gamma$ grains with high-angle grain boundaries within the $\alpha^{\prime}$-martensite laths. The $\gamma$ nuclei grow within the $\alpha^{\prime}$-martensite laths to form the final $\gamma$ microstructure. ${ }^{[6,7]}$ At high rolling reductions ( $\gtrsim 90 \mathrm{pct}$ ), the presence of two types of $\alpha^{\prime}$-martensite morphologies can be observed within the same sample due to the transformation of some deformation-induced lath type $\alpha^{\prime}$-martensite to dislocation cell-type $\alpha^{\prime}$-martensite with the increasing strain. ${ }^{[8]}$ For a fixed annealing time, $\gamma$ nucleates and grows preferentially and earlier in dislocation cell $\alpha^{\prime}$-martensite containing a high dislocation density and slip bands compared to lath type $\alpha^{\prime}$-martensite, which in turn leads to a wide range of $\gamma$ grain sizes during diffusional reversion. ${ }^{[8]}$ The operation of the Kurdjumov-Sachs orientation relationship (K-S OR, (111) $\left\|_{\gamma}\right\|(110)_{\alpha^{\prime}}$, $\left.[\overline{1} 10]_{\gamma} \|[\overline{1} 11]_{\alpha^{\prime}}\right)$ is followed between $\gamma$ and $\alpha^{\prime}$-martensite during both displacive and diffusional $\alpha^{\prime}$-martensite reversion. ${ }^{[9]}$

The reversion of $\alpha^{\prime}$-martensite via displacive/diffusional transformation depends on several factors such as the (i) heating rate, ${ }^{[10]}$ (ii) change in free energy with annealing temperature and chemical composition, and (iii) $\alpha^{\prime}$-martensite morphology. ${ }^{[11]}$ High heating rates $\left(>10{ }^{\circ} \mathrm{C} \mathrm{s}^{-1}\right)$ were reported to favor displacive $\alpha^{\prime}$-martensite reversion as less time is available for the diffusion of different elements. With regard to the chemical composition effect, higher ratios of $\gamma / \alpha$ (bcc ferrite) stabilizers were found to increase the change in free energy, thus reducing the critical temperature for displacive $\alpha^{\prime}$-martensite transformation. ${ }^{[6,12]} \alpha^{\prime}$-martensite with a lath morphology and randomly arranged dislocations was reported to revert via a displacive transformation, ${ }^{[11,13]}$ whereas $\alpha^{\prime}$-martensite with a blocky morphology and dislocation cell structure undergoes diffusional transformation. ${ }^{[11]}$

Several ex situ studies ${ }^{[4,6,10,14,15]}$ have investigated the reversion mechanisms of $\varepsilon^{-}$and $\alpha^{\prime}$-martensite during the annealing of cold-rolled metastable austenitic steels. For 50 pct cold-rolled $\mathrm{Fe}-22 \mathrm{Mn}-0.4 \mathrm{C}$ steel (in wt pet from here on), dilatometry experiments with heating rates between 0.1 and $100{ }^{\circ} \mathrm{C} \mathrm{s}^{-1}$ showed a negligible change in the start and finish reversion temperatures of $\varepsilon$-martensite, which indicates the occurrence of a displacive transformation. ${ }^{[4]}$ The displacive reversion of $\alpha^{\prime}$-martensite was observed in a 73.5 pct cold-rolled Fe-16Cr-10Ni-0.008C metastable austenitic stainless steel annealed at $900{ }^{\circ} \mathrm{C}$ for 1 second ${ }^{[16]}$ and a 90 pct cold-rolled $\mathrm{Fe}-18 \mathrm{Cr}-9 \mathrm{Ni}$ steel (with $\mathrm{C}$ content less than $0.005 \mathrm{wt}$ pct) annealed at $750^{\circ} \mathrm{C}$ for 10 seconds. $^{[6]}$ During annealing of an Fe-3Si-13Cr-7Ni steel (subjected to solution treatment at $1050{ }^{\circ} \mathrm{C}$ for 30 minutes followed by quenching), heating rates higher and lower than $10^{\circ} \mathrm{C} \mathrm{s}^{-1}$ led to displacive and diffusional $\alpha^{\prime}$-martensite reversion, respectively. ${ }^{[10]}$ For 60 pct cold-rolled Fe-(5-9)Mn-0.05C steels, dilatometry experiments showed displacive and diffusional $\alpha^{\prime}$-martensite reversions at heating rates higher and lower than 15 ${ }^{\circ} \mathrm{C} \mathrm{s}^{-1}$, respectively. ${ }^{[17]}$ All the former studies ${ }^{[4,10,15]}$ employed postmortem microstructural analysis to investigate the $\varepsilon^{-}$and $\alpha^{\prime}$-martensite reversion mechanisms, such that they do not directly observe the changes occurring during the reversion/annealing process.

Very few in situ annealing studies ${ }^{\left[3, P_{8}-20\right]}$ have been undertaken on high $\mathrm{Mn}$ steels using transmission electron microscopy (TEM) to track the reversion mechanisms of $\varepsilon^{-}$and $\alpha^{\prime}$-martensite. For an Fe-24Mn-6Si alloy (solution treated at $1000{ }^{\circ} \mathrm{C}$ for 3600 seconds followed by quenching to produce an $\varepsilon$-martensite fraction of 30 pct in the initial austenitic microstructure), in situ TEM heating to $227^{\circ} \mathrm{C}$ led to $\varepsilon$-martensite reversion, which resulted in the formation of $\gamma / \varepsilon$-martensite lamellae. ${ }^{[3]}$ For an Fe-20Ni-5Mn alloy (subjected to prior annealing at $1150{ }^{\circ} \mathrm{C}$ for $14400 \mathrm{sec}-$ onds followed by quenching to $-80{ }^{\circ} \mathrm{C}$ to produce $\alpha^{\prime}$-martensite with lath morphology), in situ TEM heating at $550{ }^{\circ} \mathrm{C}$ for 600 seconds led to diffusional reversion of $\alpha^{\prime}$-martensite with the nucleation of $\gamma$ at the preexisting twin boundaries in $\alpha^{\prime}$-martensite. ${ }^{[21]}$ For an Fe-20Ni-5.4Mn alloy (subjected to prior annealing at $1200{ }^{\circ} \mathrm{C}$ for 3600 seconds followed by quenching to $-80{ }^{\circ} \mathrm{C}$ to produce $\alpha^{\prime}$-martensite with lath morphology), in situ TEM heating at $560{ }^{\circ} \mathrm{C}$ for 135 seconds showed diffusional $\alpha^{\prime}$-martensite reversion via the migration of the $\gamma / \alpha^{\prime}$-martensite interface by the fast motion in the direction normal to the interface and slow lateral motion of ledges on the interface. ${ }^{[18]}$ For an $\mathrm{Fe}-5 \mathrm{Mn}-0.2 \mathrm{C}$ steel (subjected to prior annealing at $1200{ }^{\circ} \mathrm{C}$ for 1800 seconds followed by quenching to $28{ }^{\circ} \mathrm{C}$ to produce $\alpha^{\prime}$-lath martensite), in situ annealing at $650{ }^{\circ} \mathrm{C}$ for 257 seconds resulted in diffusional reversion of $\alpha^{\prime}$-martensite occurring via the nucleation and growth of $\gamma$ at the $\alpha^{\prime}$-martensite lath boundaries. ${ }^{[22]}$

Our previous ex situ annealing study of high Mn steel tracked the reversion of $\varepsilon^{-}$and $\alpha^{\prime}$-martensite to $\gamma$ in multiple samples heated to different temperatures. ${ }^{[23]}$ However, the $\varepsilon$ - and $\alpha^{\prime}$-martensite reversion mechanisms can be better investigated via in situ annealing experiments. To our knowledge, the literature does not contain any in situ annealing studies of $\varepsilon$ - and $\alpha^{\prime}$-martensite reversions in high $\mathrm{Mn}$ steels. Thus, the present investigation tracks the evolution of the microstructure and $\varepsilon$ - and $\alpha^{\prime}$-martensite reversion mechanisms during the in situ annealing of an Fe-17Mn-3Al-2Si-1 Ni-0.06C steel. Our previous ex situ annealing study of the same high Mn steel also showed the formation of twins in reverted $\gamma \cdot{ }^{[23]}$ In the present follow-up in situ annealing work, the mechanism of twin formation in reverted $\gamma$ is explored.

\section{EXPERIMENTAL PROCEDURE}

A high $\mathrm{Mn}$ steel with a nominal composition of Fe-17Mn-3Al-2Si-1Ni-0.06C was slab cast followed by reheating at $1100{ }^{\circ} \mathrm{C}$ for 7200 seconds. The slab was subjected to 52.5 pct hot rolling in four passes at 1100 ${ }^{\circ} \mathrm{C}$ followed by 42 pct cold rolling in 11 passes to a final thickness of $\approx 5.4 \mathrm{~mm}$. Samples were cut from the normal direction (ND) - rolling direction (RD) plane followed by grinding to prepare thin foils. Disks of $3 \mathrm{~mm}$ diameter were punched and twin jet 
electropolished using a Struers Tenupol-5 operating at $30 \mathrm{~V}(\approx 150 \mathrm{~mA})$ with a solution of 90 pct methanol and 10 pct perchloric acid at a temperature of $-25^{\circ} \mathrm{C}$. In situ heating of the thin foils was carried out in a JEOL $2200 \mathrm{FS}$ transmission electron microscope operating at $200 \mathrm{kV}$ using a Gatan double-tilt heating stage at the University of Sydney. The heating experiments were performed using a heating rate of $20{ }^{\circ} \mathrm{C} \mathrm{min}{ }^{-1}$. Analysis of the diffraction patterns was carried out utilizing the diffraction pattern analysis plugins ${ }^{[24]}$ within the Digital Micrograph software (Gatan Inc.). The Java electron microscopy simulation (JEMS) software ${ }^{[25]}$ was used for the simulation of the diffraction patterns.

\section{RESULTS AND DISCUSSION}

Figure 1 shows the evolution of $\varepsilon$-martensite (with a representative diffraction pattern shown as an inset in Figure 1(a)) during in situ heating. The presence of stacking faults in $\varepsilon$-martensite due to deformation accommodation during prior cold rolling is evident in Figure 1(a) and marked by white arrows in the magnified view in Figure 1(b). Within a single grain at the same specimen tilt, the density of stacking faults in the regions marked by white arrows are observed to decrease with the increasing temperature to $390{ }^{\circ} \mathrm{C}$ (Figures 1(b) through (d)). Tomota et al. ${ }^{[3]}$ reported a similar reduction in the density of stacking faults in $\varepsilon$-martensite prior to its reversion to $\gamma$ during in situ annealing of an Fe-24Mn-6Si alloy. The internal crystal structure is observed to change due to the reversion of $\varepsilon$-martensite to $\gamma$ as verified by the inset diffraction pattern in Figure 1(e). Moreover, the superimposition of the micrographs after heating to $390{ }^{\circ} \mathrm{C}$ and $410{ }^{\circ} \mathrm{C}$ showed no change in shape and size of the parent $\varepsilon$-martensite grain $\left(\right.$ at $390{ }^{\circ} \mathrm{C}$ ) and daughter reverted $\gamma$ grain (at $410{ }^{\circ} \mathrm{C}$ ). Also on heating from $390{ }^{\circ} \mathrm{C}$ to $410{ }^{\circ} \mathrm{C}$ a jump of the foil was detected during our in situ heating experiment, which is typically associated with phase transformation. Upon further heating to $650{ }^{\circ} \mathrm{C}$ (Figure 1(f)), remnant dislocations (highlighted by white arrows) are still observed in $\gamma$ due to its low stacking fault energy $\left(\mathrm{SFE}=14.5 \mathrm{~mJ} \mathrm{~m}^{-2[26]}\right.$ ), which in turn, leads to limited recovery. The remnant faults present in the reverted $\gamma$ at $410{ }^{\circ} \mathrm{C}$ disappeared upon heating to $650{ }^{\circ} \mathrm{C}$.

The diffraction pattern of $\gamma$ was simulated from the known $[\overline{2} 4 \overline{2} 3]_{\varepsilon} \varepsilon$-martensite zone axis using the S-N OR. ${ }^{[5]}$ The simulated diffraction pattern (Figure 2(a)) shows that the $(10 \overline{1} 0)_{\varepsilon} /(02 \overline{2})_{\gamma}, \quad(01 \overline{1} \overline{2})_{\varepsilon} /(\overline{4} 0 \overline{2})_{\gamma}$ and $(11 \overline{2} \overline{2})_{\varepsilon} /(\overline{4} 2 \overline{2})_{\gamma}$ spot pairs are very closely spaced. The evolution of the spacing of these spot pairs with temperature is given in Figure 2(b). The abrupt decrease in the spot spacing of $(11 \overline{2} \overline{2})_{\varepsilon} /(\overline{4} 2 \overline{2})_{\gamma}$ and $(01 \overline{1} \overline{2})_{\varepsilon} /(\overline{4} 0 \overline{2})_{\gamma}$ at $410{ }^{\circ} \mathrm{C}$ indicates the reverse transformation to $\gamma$.

During $\varepsilon$-martensite reversion to $\gamma$, the $[1 \overline{2} 10]_{\varepsilon}$ zone axis should be used when imaging $\varepsilon$-martensite to track the $\gamma / \varepsilon$-martensite interface as the interface is in the edge-on condition at the $[1 \overline{2} 10]_{\varepsilon}$ zone axis and thus suitable for determining its exact position. ${ }^{[3,27]}$ The $[\overline{2} 4 \overline{2} 3]_{\varepsilon}$ zone axis used here makes an angle of $24.7 \mathrm{deg}$ with the ideal $[1 \overline{2} 10]_{\varepsilon}$ zone axis. Although the $\gamma /$ $\varepsilon$-martensite interface is not in the edge-on condition for the $[\overline{2} 4 \overline{2} 3]_{\varepsilon}$ zone axis, the migration of the inclined $\gamma /$ $\varepsilon$-martensite interface should be possible to detect, yet this was not observed. Thus, the reverse transformation occurred across the entire grain without the movement of the $\gamma / \varepsilon$-martensite interface. The above observations (no change in shape and size of the parent $\varepsilon$-martensite grain and no $\gamma / \varepsilon$-martensite interface migration) indicate the displacive reversion of $\varepsilon$-martensite to $\gamma$. Similar to the case shown in Figure 1, tracking an $\varepsilon$-martensite grain (Figure 3) in another sample showed that the density of stacking faults observed in the cold-rolled condition (Figures 3(a) and (b)) was reduced upon heating to $400{ }^{\circ} \mathrm{C}$ (Figure 3(c)). While further heating to $420^{\circ} \mathrm{C}$ (Figure $3(\mathrm{~d})$ ) does not lead to any change in the grain shape, the recorded diffraction pattern (Figure 3(d), inset) clearly indicates the reversion of $\varepsilon$-martensite to $\gamma$.

Using the known initial orientation of $\varepsilon$-martensite with $[7 \overline{2} \overline{5} 3]_{\varepsilon}$ zone axis (Figure $3(\mathrm{a})$, inset) the diffraction pattern of the reverted $\gamma$ was simulated assuming the operation of S-N OR (Figure 3(e)) and was found to match the experimental diffraction pattern (Figure 3(d), inset). The $[7 \overline{2} \overline{5} 3]_{\varepsilon}$ zone axis makes an angle of $19.8 \mathrm{deg}$ with the $[1 \overline{2} 10]_{\varepsilon}$ zone axis. Similar to the previous case in Figure 1 and although the $\gamma / \varepsilon$-martensite interface not in the edge-on condition, the migration of the inclined $\gamma /$ $\varepsilon$-martensite interface should be possible to detect, but still it was not visible. Consequently, the above observations also indicate the operation of displacive transformation in this $\varepsilon$-martensite grain.

Tomota et al. ${ }^{[3]}$ during the in situ heating of an $\mathrm{Fe}-24 \mathrm{Mn}$ alloy (subjected to solution treatment at $1000{ }^{\circ} \mathrm{C}$ for 3600 seconds followed by quenching) observed the displacive reversion of $\varepsilon$-martensite to $\gamma$. However, the formation of reverted $\gamma$ reported by Tomota et al. ${ }^{[3]}$ was different in comparison to the present study. Tomota et al. ${ }^{[3]}$ observed the $\varepsilon$-martensite reverse transformation to start from the inside and outside of the $\varepsilon$-martensite plates. This was due to the presence of $\gamma$ and $\varepsilon$-martensite in the initial microstructure such that the preexisting $\gamma$ provides nucleation sites for reverted $\gamma$. In such a case, the $\varepsilon$-martensite to $\gamma$ reversion leads to the formation of a thin $\gamma / \varepsilon$-martensite lamellae. ${ }^{[3]}$

On heating to $700{ }^{\circ} \mathrm{C}$, the formation of fine twins (highlighted by white arrows in Figure 4(a)) was observed in the reverted $\gamma$ grain. The twin spacing $(w)$ was calculated to be $7.6 \pm 2.3 \mathrm{~nm}$ from the measured spacing $\left(w_{\mathrm{L}}\right)$ using the following equation ${ }^{[28]}$.

$$
w=\frac{2 w_{\mathrm{L}}}{\pi} .
$$



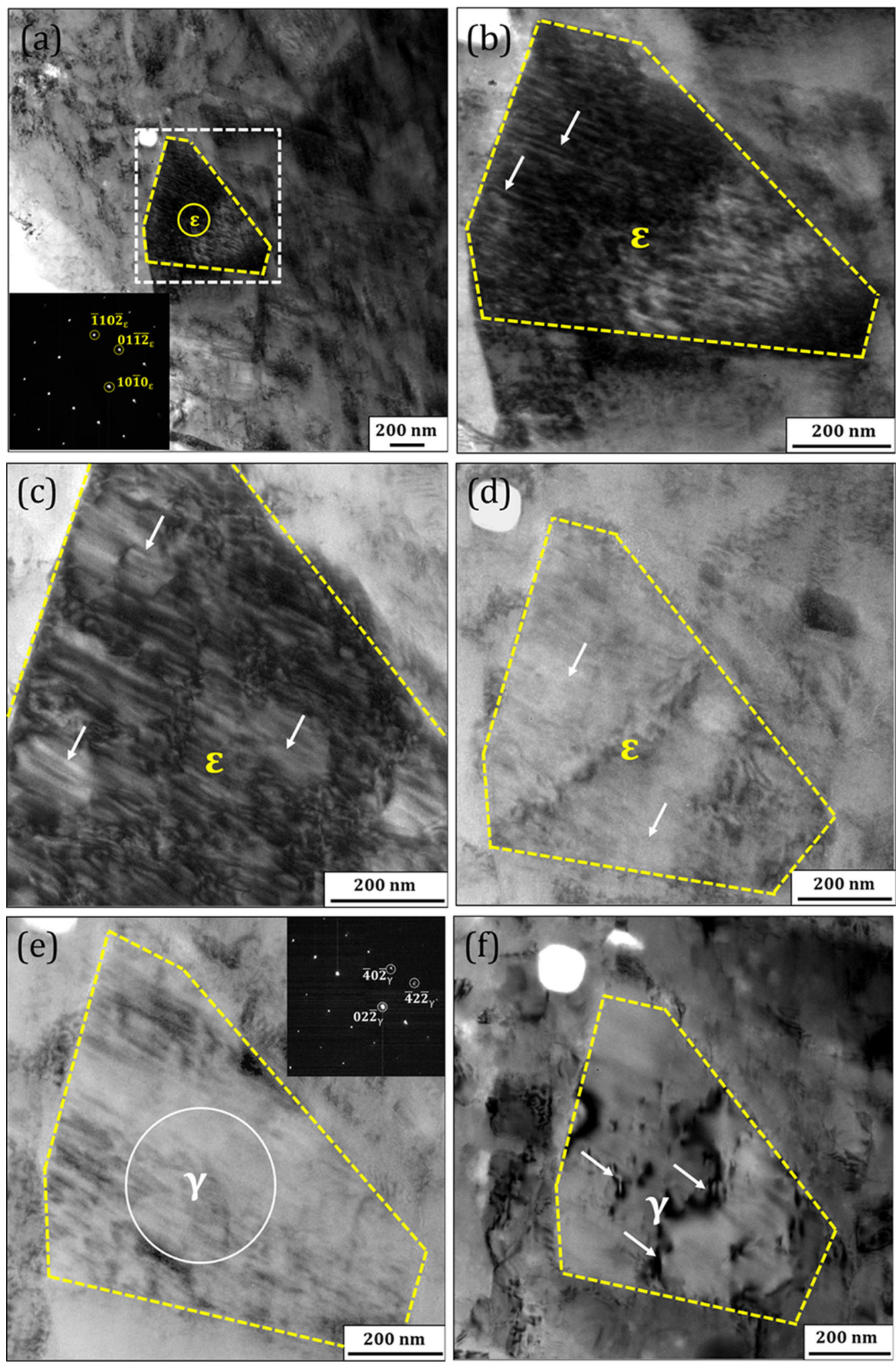

Fig. 1-Bright-field transmission electron micrographs showing ( $a$ through $d$ ) $\varepsilon$-martensite and $(e, f) \gamma$ at $(\mathrm{a}, \mathrm{b}) 2{ }^{\circ} \mathrm{C}$ (room temperature) and after in situ heating to temperatures of: (c) $240{ }^{\circ} \mathrm{C}$, (d) $390{ }^{\circ} \mathrm{C}$, (e) $410{ }^{\circ} \mathrm{C}$ and (f) $650{ }^{\circ} \mathrm{C}$. (b) is a magnified view of the white dashed rectangle in (a). The inset diffraction patterns were obtained from the solid circles in (a) and (e) for the zone axes [2423] and [122], respectively. The white arrows in (b) through (d) and (f) indicate $\varepsilon$-martensite stacking faults and remnant dislocations, respectively. 


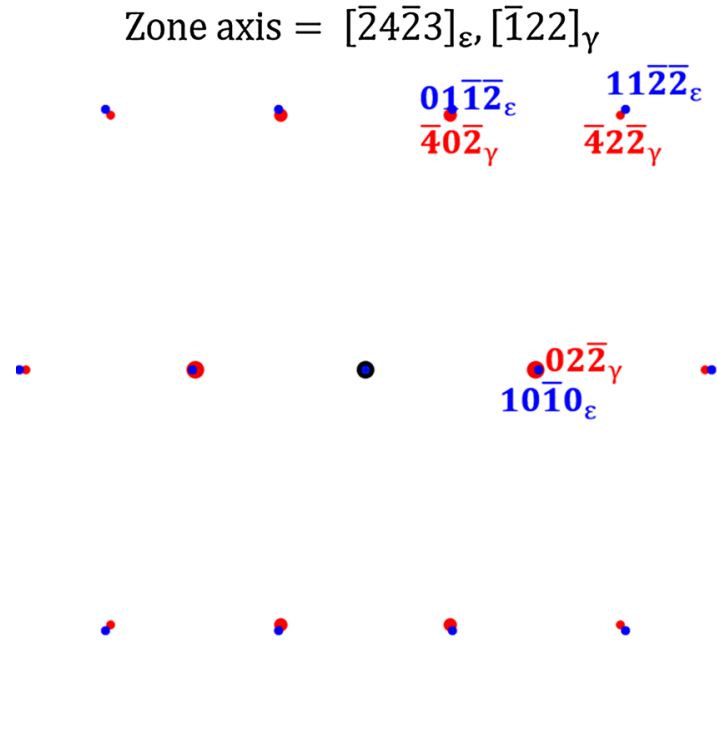

(a)

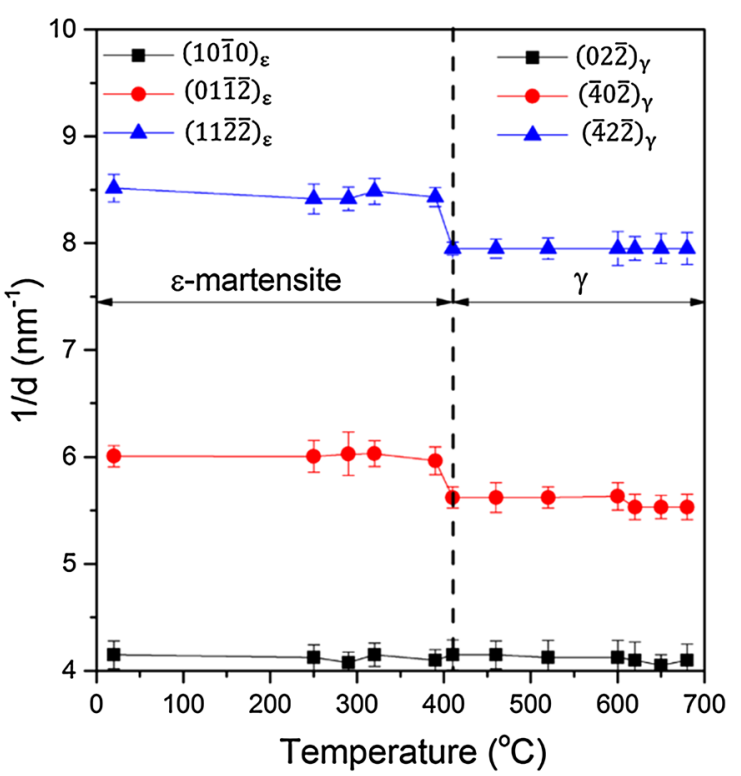

(b)

Fig. 2 - (a) Simulated diffraction pattern of $\gamma / \varepsilon$-martensite based on the Shoji-Nishiyama orientation relationship for the $[\overline{2} 4 \overline{2} 3]$ zone axis and (b) the evolution of spot spacing of $\gamma / \varepsilon$-martensite reflections with temperature. The red and blue spots in (a) are for $\gamma$ and $\varepsilon$-martensite, respectively (Color figure online).

It is noted that the twin reflections are not readily seen in the $\gamma$ diffraction pattern (Figure 4(a), inset*) due to the

\footnotetext{
*The additional weak reflections/streaks in the inset diffraction pattern in Figure 4(a) are due to the oxidation of the foil at high temperature. The lower (bright) region of Figure 4(a) shows areas where the foil has oxidized through its full thickness. In other (darker) regions, mottled contrast indicates that an oxide skin has formed on the surfaces of the foil.
}

overlap between the twins and $\gamma$ main reflections. The simulated diffraction pattern in Figure 4(b) clearly demonstrates the overlap between the $(1 \overline{1} 3)_{\gamma}$ twin and $(31 \overline{1})_{\gamma}$ spots. Since $\gamma$ recrystallization was not detected after heating to $700{ }^{\circ} \mathrm{C}$ (Figure 4(a)), the observed twins likely formed due to recovery. The formation of twins in $\gamma$ reverted from $\alpha^{\prime}$-martensite was reported during the annealing of 98 pct cold-rolled Fe-33.5Ni alloy initially containing $\gamma$ and $\alpha^{\prime}$-martensite. ${ }^{[29]}$ Therein, fine twins were observed after heating to $50{ }^{\circ} \mathrm{C}$ above the $\alpha^{\prime}$-martensite reversion temperature during the early stage of $\gamma$ recovery. Twin formation in reverted $\gamma$ was also observed during the in situ TEM annealing of an Fe-5Mn- $0.2 \mathrm{C}$ steel at $650{ }^{\circ} \mathrm{C} .^{[22]}$ Furthermore, the formation of fine recovery twins was reported during the early stages of annealing of other cold-rolled low SFE fcc materials such as brass ${ }^{[30,31]}$ and $\mathrm{Co}-\mathrm{Cr}-\mathrm{Mo}$ alloy. ${ }^{[32]}$

A schematic diagram detailing our proposed mechanism for $\varepsilon$-martensite reversion and the subsequent $\gamma$ twin formation is presented in Figure 5. Earlier studies on the same steel by Saleh et al. ${ }^{[33]}$ and Gazder et al. ${ }^{[15,34]}$ showed that $\varepsilon$-martensite can accommodate deformation via basal slip and the formation of stacking faults. In a detailed follow-up study, ${ }^{[35]}$ atomic resolution scanning transmission electron microscopy analysis of $\varepsilon$-martensite revealed the presence of intrinsic stacking faults (ISF)** of type $\mathrm{I}_{1}$ in the

\footnotetext{
**The motion of a Shockley partial dislocation on a closed packed plane in $\varepsilon$-martensite creates intrinsic stacking faults of two types, $I_{1}$ and $\mathrm{I}_{2}$. Creation of $\mathrm{I}_{1}$ type $\varepsilon$-ISF occurs by the removal of one layer of basal plane atoms followed by slip along $\frac{a}{3}[10 \overline{1} 0]_{\varepsilon}$ which is described as $\mathrm{ABABABAB} \rightarrow \mathrm{ABAB} \mid \mathrm{CBCB}$. An $\mathrm{I}_{2}$ type $\varepsilon$-ISF is created by the motion of Shockley partial dislocations and is described as $\mathrm{ABABABAB} \rightarrow \mathrm{ABAB}|\mathrm{C}|$ ACAC.
}

42 pct cold-rolled sample. On heating to $420^{\circ} \mathrm{C}$, the reversion of this faulted $\varepsilon$-martensite can occur by the motion of Shockley partial dislocations with Burgers vectors $\frac{a}{3}[10 \overline{1} 0]_{\varepsilon}$ (where a is $\varepsilon$-martensite lattice parameter) on alternate planes. ${ }^{[36,37]}$ The net shear due to the propagation of two Shockley partial dislocations is $\frac{2 a}{3}[10 \overline{1} 0]_{\varepsilon}$ just below the plane of the $\varepsilon$-ISF $\left(\mathrm{I}_{1}\right)$. In addition, Shockley partial dislocations do not pass on alternate planes of $\varepsilon$-martensite due to the presence of $\mathrm{I}_{1}$-type $\varepsilon$-ISFs. Shearing by the $\frac{a}{3}[10 \overline{1} 0]_{\varepsilon}$ dislocations lead to the transformation of $\mathrm{I}_{1}$-type $\varepsilon$-ISFs into a $\gamma$-ISF in the reverted $\gamma$ lattice. The presence of faint contrast due to faults in reverted $\gamma$ is highlighted by white arrows in Figure 3(d). The thickening of these $\gamma$-ISFs is likely to occur by the migration of Shockley partial dislocations $\frac{a}{6}[11 \overline{2}]_{\gamma}$ (where $a$ is the lattice parameter of $\gamma$ ) adjacent to the $\gamma$-ISF $(111) \gamma$ planes during further heating to $700{ }^{\circ} \mathrm{C}$. This, in turn, leads to a change in the local stacking sequence to that of $\gamma$ twins. A macroscopic twin then forms as more and more Shockley partial dislocations glide together. 

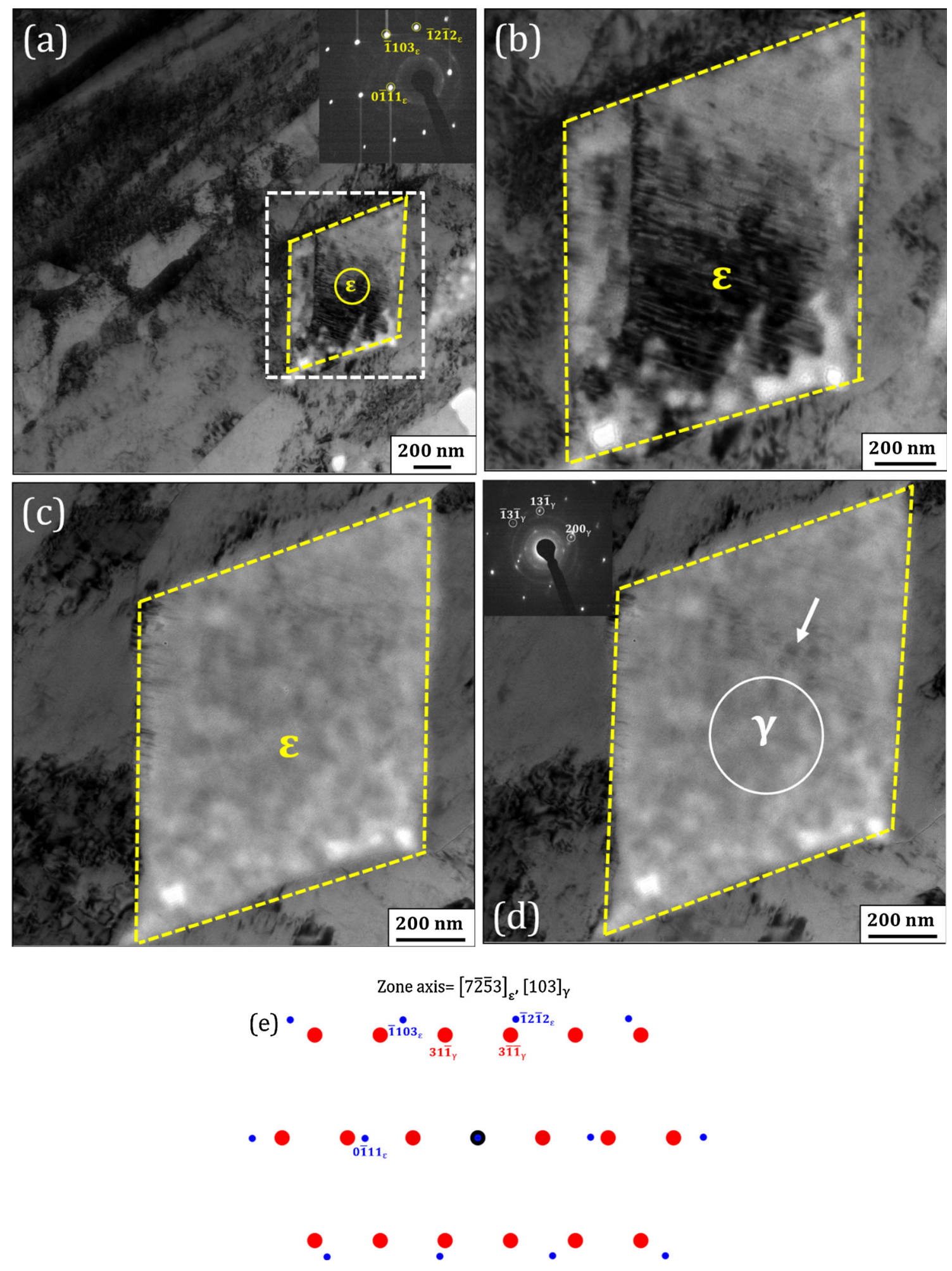

Fig. 3-Bright-field transmission electron micrographs of ( $a$ through $c$ ) $\varepsilon$-martensite and $(d) \gamma$ at $(\mathrm{a}, \mathrm{b}) 2{ }^{\circ} \mathrm{C}$ (room temperature) and after in situ heating to (c) $400{ }^{\circ} \mathrm{C}$, (d) $420{ }^{\circ} \mathrm{C}$ and (e) simulated diffraction pattern of $\gamma / \varepsilon$-martensite by Shoji-Nishiyama orientation relationship for the $[7 \overline{2} \overline{5} 3]_{\text {. }}$ zone axis. The inset diffraction patterns were obtained from the circled regions in (a) and (d) for the zone axis $[7 \overline{2} \overline{5} 3]_{\varepsilon}$ and $[103]_{\gamma}$, respectively. In (e), the red and blue spots are for $\gamma$ and $\varepsilon$-martensite, respectively (Color figure online).

Figure 6 shows the same region in Figure 3 after heating to $800^{\circ} \mathrm{C}$. The bright-field TEM micrograph at $800{ }^{\circ} \mathrm{C}$ and the corresponding selected area diffraction pattern (inset, Figure 6(a)) shows elongated $\alpha^{\prime}$-martensite grains which were produced by prior cold rolling. After isothermal holding for 600 seconds at $800{ }^{\circ} \mathrm{C}$ 


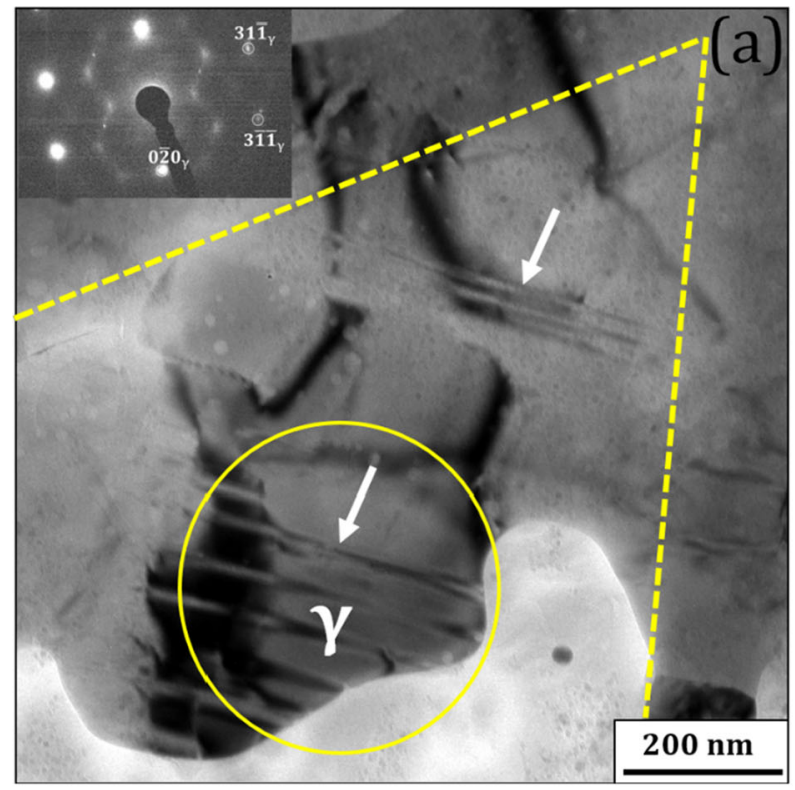

(b) Zone axis= $[103]_{\gamma}$

.

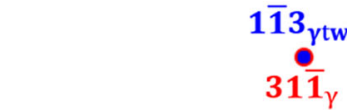

-

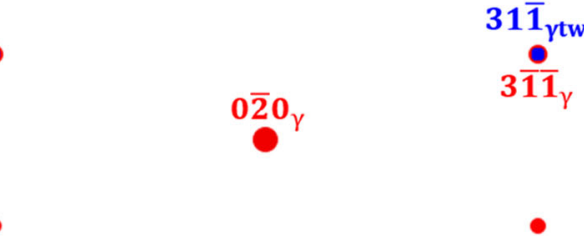

Fig. 4-Bright-field transmission electron micrograph of $(a) \gamma$ after in situ heating to $700{ }^{\circ} \mathrm{C}$ and $(b)$ simulated diffraction pattern of $\gamma / \gamma$ twin $\left(\gamma_{t w}\right)$ for the $[103]_{\gamma}$ zone axis. The inset diffraction pattern was obtained from the circular region in a for the zone axis [103]. In (b), the red and blue spots are for the $\gamma$ and $\gamma_{\mathrm{tw}}$, respectively (Color figure online).

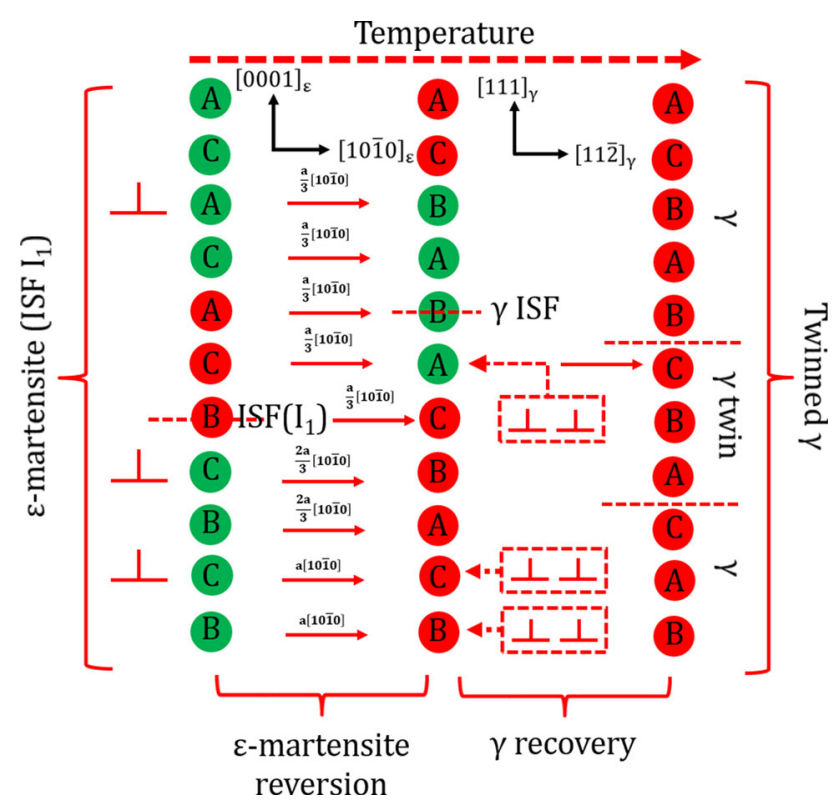

Fig. 5-A schematic diagram showing the reversion of faulted $\varepsilon$-martensite and subsequent twinning during $\gamma$ recovery, with the red and green circles representing the fcc and hcp stacking sequences, respectively, and Shockley partial dislocations shown by the symbol " $\perp$ " (Color figure online).

(Figure 6(b)), the recorded diffraction pattern (Figure 6(b), inset) clearly indicates the reversion of $\alpha^{\prime}$-martensite to $\gamma$. The diffraction pattern of $\gamma$ was simulated from the $[011]_{\alpha^{\prime}}$ zone axis pattern (Figure 6(a), inset) using the $\mathrm{K}-\mathrm{S}$ OR and is shown in Figure 6(c). Comparing the experimental and simulated diffraction patterns confirms the operation of the $\mathrm{K}-\mathrm{S}$ OR.
The $[111]_{\alpha^{\prime}} \|[011]_{\gamma}$ zone axis was used by Wu et al. ${ }^{[19]}$ to track the $\gamma / \alpha^{\prime}$-martensite interface as the migrating interface is edge-on in this condition and thus suitable for determining its exact position. The $[011]_{\alpha^{\prime}}$ zone axis used here makes an angle of $35.3 \mathrm{deg}$ with the ideal $[111]_{\alpha^{\prime}}$ zone axis. Although, the $\gamma / \alpha^{\prime}$-martensite interface is not in the edge-on condition for the $[011]_{\alpha^{\prime}} \|[111]_{\gamma}$ zone axes; the migration of the inclined $\gamma / \alpha^{\prime}$-martensite interface should be possible to detect. However, this still was not observed in the present case. It follows that the reverse transformation occurred across the entire grain without any change in the grain shape and the motion of the $\gamma / \alpha^{\prime}$-martensite interface. This, in turn, signifies the occurrence of displacive reversion of $\alpha^{\prime}$-martensite to $\gamma$.

During the annealing of an $\mathrm{Fe}-9.6 \mathrm{Ni}-7 \mathrm{Mn}$ steel (subjected to solution treatment at $950{ }^{\circ} \mathrm{C}$ for $3600 \mathrm{sec}-$ onds followed by quenching to $28^{\circ} \mathrm{C}$ ), $\alpha^{\prime}$-martensite reversion was reported to occur by diffusional and displacive mechanisms at relatively lower $\left(540{ }^{\circ} \mathrm{C}\right.$ to $\left.585^{\circ} \mathrm{C}\right)$ and higher annealing temperatures $\left(585^{\circ} \mathrm{C}\right.$ to $640{ }^{\circ} \mathrm{C}$ ), respectively. ${ }^{[12]}$ In this regard, $92.5 \mathrm{pct}$ cold-rolled $\mathrm{Fe}-12 \mathrm{Cr}-8.9 \mathrm{Ni}-4 \mathrm{Mo}-1.9 \mathrm{Cu}-1.4 \mathrm{Ti}$ steel comprising $\alpha^{\prime}$-martensite with lath morphology (without dislocation cells) was observed to revert by a displacive mechanism on heating to $750{ }^{\circ} \mathrm{C}$ at $10^{\circ} \mathrm{C} \mathrm{s}^{-1} \cdot[11]$ Thus, the present experimental conditions - the relatively high annealing temperature $\left(800{ }^{\circ} \mathrm{C}\right)$ and the presence of $\alpha^{\prime}$-martensite with lath morphology-are expected to favor the displacive reversion of $\alpha^{\prime}$-martensite (as mentioned above in the Section I).

However, due also to the high annealing temperature $\left(800{ }^{\circ} \mathrm{C}\right)$ along with the 600 seconds holding time, it can be speculated that carbon diffusion may be occurring during $\alpha^{\prime}$-martensite reversion. In this regard, carbon diffusion during the reversion of $\alpha^{\prime}$-martensite to $\gamma$ by 

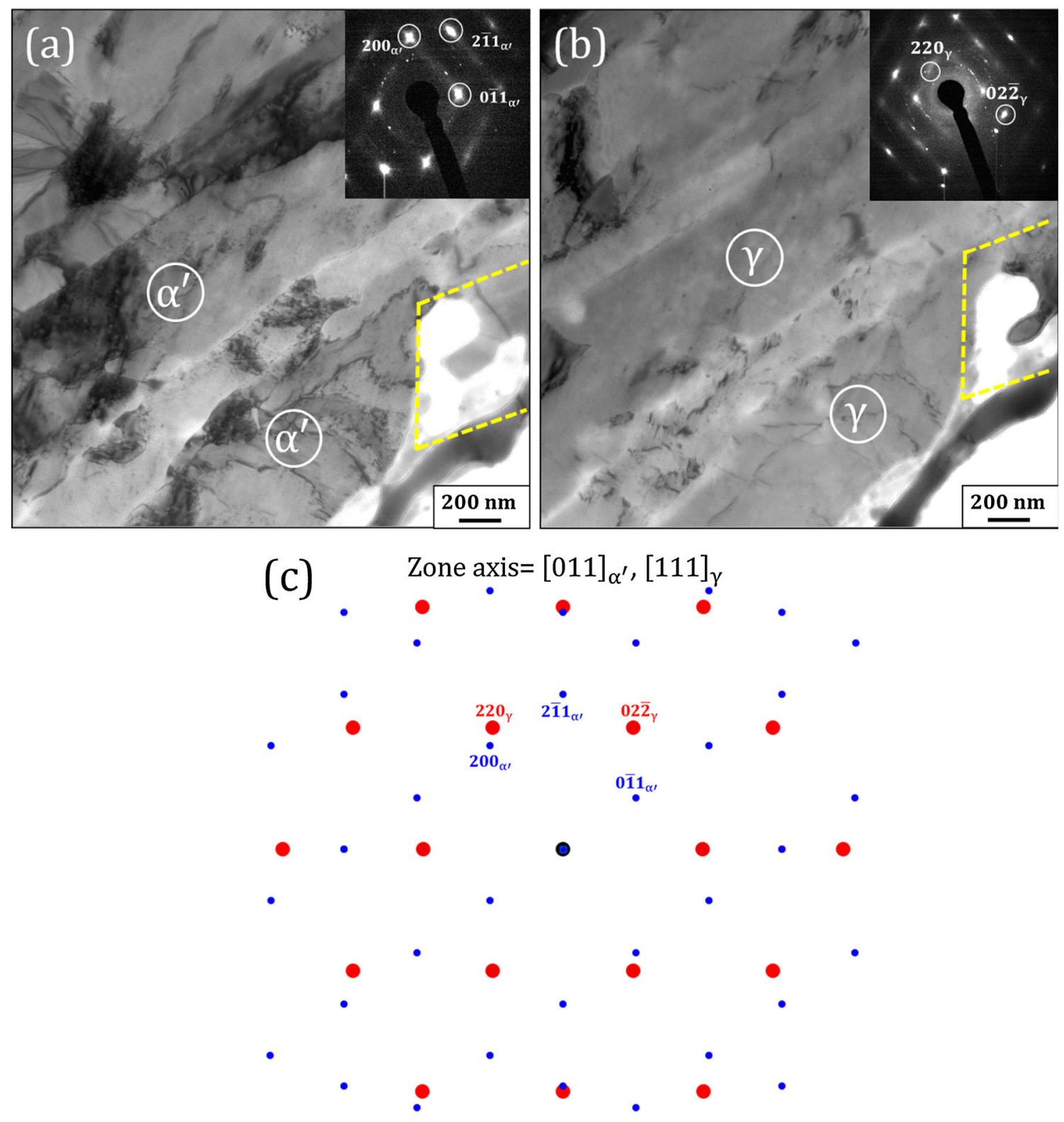

Fig. 6 - Bright-field transmission electron micrographs of (a) $\alpha^{\prime}$-martensite and (b) $\gamma$ after (a) in situ heating to $800{ }^{\circ} \mathrm{C}$, (b) holding at $800{ }^{\circ} \mathrm{C}$ for $600 \mathrm{~s}$, and $(c)$ simulated diffraction pattern of $\gamma / \alpha^{\prime}$-martensite based on the Kurdjumov-Sachs orientation relationship for the $[011]_{\alpha^{\prime}}$ zone axis. The inset diffraction patterns were obtained from the circled regions in (a) and (b) for the zone axes $[011]_{\alpha^{\prime}}$ and $[111]_{\gamma}$, respectively. In (c), the red and blue spots denote $\gamma$ and $\alpha^{\prime}$-martensite, respectively (Color figure online).

displacive transformation was suggested in an $\mathrm{Fe}-5 \mathrm{Mn}-0.15 \mathrm{C}$ steel processed by solution treatment at $1000^{\circ} \mathrm{C}$ for 1800 seconds followed by water quenching. ${ }^{[38]}$

An attempt to evaluate the possibility of displacive and diffusional $\alpha^{\prime}$-martensite reversion was also made by calculating the time required for the migration of $\mathrm{Fe}$ atoms in $\alpha^{\prime}$-martensite by diffusion. The atomic jump frequency, which is inversely proportional to the time required for the diffusional transformation, was calculated at $800{ }^{\circ} \mathrm{C}$, using the following equations ${ }^{[39]}$.

$$
D=D_{\mathrm{o}} \exp \left(\frac{-Q}{R T}\right)
$$

$$
1 / \Gamma=\alpha^{2} / 8 D,
$$

where $D$ is the diffusion coefficient in paramagnetic $\alpha^{\prime}$-martensite at $800{ }^{\circ} \mathrm{C}, D_{\mathrm{o}}$ is the frequency factor $\left(=1.92 \mathrm{~cm}^{2} \mathrm{~s}^{-1}\right), Q$ is the activation energy, $R$ is the universal gas constant $\left(=8.314 \mathrm{~J} \mathrm{~mol}^{-1} \mathrm{~K}^{-1}\right), T$ is the temperature $(\mathrm{K}), \Gamma$ is the jump frequency of an atom and $\alpha$ is the interatomic distance $\left(=2.48 \times 10^{-8} \mathrm{~cm}\right) .^{[39]}$ Using the activation energy of self-diffusion for bcc $\mathrm{Fe}$ $\left(\approx 239 \mathrm{~kJ} \mathrm{~mol}^{-1} \mathrm{~K}^{-1}\right),{ }^{[40]}$ the mean time of stay $\left(\frac{1}{\Gamma}\right)$ for $\mathrm{Fe}$ atoms at $800^{\circ} \mathrm{C}$ (i.e., the time required for diffusional transformation) is calculated to be $\approx 1.8 \times 10^{-5}$ seconds. The time required for the displacive transformation of $\gamma$ to $\alpha^{\prime}$-martensite with lath morphology was reported to 
be $\approx 10^{-5}$ seconds. ${ }^{[41]}$ Assuming the reversion time of $\alpha^{\prime}$-martensite to $\gamma$ to be the same $\left(\approx 10^{-5}\right.$ seconds $)$, the required times for diffusional and displacive transformations at $800{ }^{\circ} \mathrm{C}$ are similar. Consequently, based on the above calculations, either of the reversion mechanisms (diffusional/displacive) could be operational.

The $\alpha^{\prime}$-martensite reversion mechanism also depends on the availability of a constraint-free sample surface present in thin foils compared to bulk samples. Previous investigations ${ }^{[42-46]}$ suggested a strong correlation between the presence of a sample surface and displacive $\alpha^{\prime}$-martensite transformation. During the in situ observations using a laser scanning confocal microscope of an $\mathrm{Fe}-7.1 \mathrm{Ni}-2 \mathrm{Mn}-0.03 \mathrm{C}$ steel (processed by annealing at $1100{ }^{\circ} \mathrm{C}$ for 3 minutes followed by quenching), displacive transformation of $\alpha^{\prime}$-martensite was noted at $452{ }^{\circ} \mathrm{C}$ at the sample surface, compared to $338{ }^{\circ} \mathrm{C}$ within the bulk. ${ }^{[43]}$ This indicates that lower undercooling (driving force) is required at the surface. Here, the occurrence of $\alpha^{\prime}$-martensite transformation at the sample surface leads to a reduction in the stain energy (due to the shape change associated with the formation of $\alpha^{\prime}$-martensite) which in turn supports displacive transformation. Similarly, during the formation of $\alpha^{\prime}$-martensite in an Fe-30Ni-0.04C single crystal, the $\alpha^{\prime}$-martensite start temperature at the sample surface was found to be higher $\left(5{ }^{\circ} \mathrm{C}\right.$ to $\left.30{ }^{\circ} \mathrm{C}\right)$ than the bulk interior, which again indicates that a lower undercooling is required at the surface. ${ }^{[42]}$ This was also attributed to the availability of a free surface which assisted in the relief of shear strain caused by the displacive transformation of $\alpha^{\prime}$-martensite. For an Fe-6Mn-16Cr-3Ni-0.03C duplex stainless steel, the creation of a trench of a width and depth of $1 \mu \mathrm{m}$ was undertaken by focussed ion beam milling to form a free surface. The formation of a free surface led to the transformation of the neighboring retained $\gamma$ grain to $\alpha^{\prime}$-martensite. ${ }^{[4]}$ This was again ascribed to the lowering of the $\alpha^{\prime}$-martensite nucleation barrier as the strain energy is reduced, and consequently favoring displacive transformation. In this regard, the recovery of the $\alpha^{\prime}$-martensite surface relief (i.e., negative shape strain) was observed during $\alpha^{\prime}$-martensite reversion to $\gamma$ in an Fe-31Ni-0.4C alloy (processed by solution treatment at $1197{ }^{\circ} \mathrm{C}$ for 3600 seconds followed by quenching). ${ }^{[47]}$ This negative shape strain due to displacive transformation is expected to be accommodated easily on the surface of thin foils compared to bulk samples. Thus, the availability of free surface in thin foils is expected to favor displacive $\alpha^{\prime}$-martensite reversion in the present investigation.

With the above in mind, it is emphasized that $\alpha^{\prime}$-martensite reversion mechanism can differ during in situ heating of thin foils compared to postmortem observations on annealed bulk samples. It follows that more experimental work is required to draw a definite conclusion and to support the proposition of displacive $\alpha^{\prime}$-martensite reversion in the present steel.

$\varepsilon^{-}$and $\alpha^{\prime}$-martensite reversion temperatures are typically higher during heating of thin foils compared to bulk samples. While $\varepsilon$-martensite reversion in the present study was not observed up to $400{ }^{\circ} \mathrm{C}$, heating of bulk samples by dilatometry returned a relatively lower reversion temperature range of $100{ }^{\circ} \mathrm{C}$ to $250{ }^{\circ} \mathrm{C} .{ }^{[48]}$

During the in situ heating of thin foils of an Fe-24Mn-6Si alloy, comprising an initial microstructure of $\gamma(70 \mathrm{pct})$ and $\varepsilon$-martensite (30 pct), $\varepsilon$-martensite reversion was noted at $227^{\circ} \mathrm{C}$ as opposed to $183{ }^{\circ} \mathrm{C}$ for bulk samples. ${ }^{[3]}$ The higher variation in the reversion temperatures in the present study compared to Reference 3 is likely due to the difference in composition and the initial microstructures.

While $\alpha^{\prime}$-martensite reversion in the present experiment was not observed upon heating between $600{ }^{\circ} \mathrm{C}$ and $800^{\circ} \mathrm{C}$, heating of bulk samples by dilatometry returned a relatively lower reversion temperature range of between $500{ }^{\circ} \mathrm{C}$ and $700{ }^{\circ} \mathrm{C} \cdot{ }^{[48]}$ Similarly, during the in situ heating of thin foils of an Fe-20Ni-5Mn alloy (processed by 60 pct cold rolling and subsequent annealing at $1200{ }^{\circ} \mathrm{C}$ for 3600 seconds followed by quenching) comprising an initial microstructure of $\gamma$ and $\alpha^{\prime}$-martensite with lath morphology, reversion was noted at $550{ }^{\circ} \mathrm{C}$, which is higher than the temperature for the bulk samples $\left(400^{\circ} \mathrm{C}\right) \cdot{ }^{[19]}$

The theoretical $\alpha^{\prime}$-martensite transformation temperature $\left(T_{\mathrm{o}}\right)$ at which the free energy of $\gamma$ and $\alpha^{\prime}$-martensite is equal $\left(G^{\alpha}=G^{\gamma}\right)$ was estimated by observing the change in the free energy for $\alpha^{\prime}$-martensite reversion $\left(\Delta G^{\alpha-\gamma}, \mathrm{J} / \mathrm{mol}\right)$ for our Fe-17Mn-3Al-2Si-1Ni-0.06C steel using the following equations ${ }^{[6,49,50]}$ :

$$
\begin{aligned}
\Delta G^{\alpha-\gamma}= & 10^{-2}\left(\Delta G_{\mathrm{Fe}}^{\alpha-\gamma}\right)\left(100-\mathrm{Cr}_{\mathrm{eq}}-\mathrm{Ni}_{\mathrm{eq}}\right) \\
& -\left(97.5 \times \mathrm{Cr}_{\mathrm{eq}}\right)+\left(2.02 \mathrm{Cr}_{\mathrm{eq}} \times \mathrm{Cr}_{\mathrm{eq}}\right) \\
& -108.8 \mathrm{Ni}_{\mathrm{eq}}+\left(0.52 \mathrm{Ni}_{\mathrm{eq}} \times \mathrm{Ni}_{\mathrm{eq}}\right) \\
& -0.05\left(\mathrm{Cr}_{\mathrm{eq}} \times \mathrm{Ni}_{\mathrm{eq}}\right)+10^{-3}\left(73.3 \times \mathrm{Cr}_{\mathrm{eq}}-0.67\right. \\
& \times \mathrm{Cr}_{\mathrm{eq}} \times \mathrm{Cr}_{\mathrm{eq}}+50.2 \times \mathrm{Ni}_{\mathrm{eq}}-0.84 \times \mathrm{Ni}_{\mathrm{eq}} \\
& \left.\times \mathrm{Ni}_{\mathrm{eq}}-1.51 \times \mathrm{Cr}_{\mathrm{eq}} \times \mathrm{Ni}_{\mathrm{eq}}\right) \\
\Delta \mathrm{G}_{\mathrm{Fe}}^{\alpha-\gamma}=6190.8-14.3 \times 10^{-2} \mathrm{~T}^{2}+2 \times 10^{-6} \mathrm{~T}^{3} & \\
& \left.\quad \mathrm{Cr}_{\mathrm{eq}}=\mathrm{Cr}+4.5 \times \mathrm{Mo}\right] \\
\mathrm{Ni}_{\mathrm{eq}}= & \mathrm{Ni}+0.6 \times \mathrm{Mn}+20 \times \mathrm{C}+4 \times \mathrm{N}+0.4 \times \mathrm{Si}
\end{aligned}
$$

where, $\Delta G_{\mathrm{Fe}}^{\alpha-\gamma}(\mathrm{J} / \mathrm{mol})$ is the free energy of pure iron $(\mathrm{Fe})$, $T(\mathrm{~K})$ is the temperature, $\mathrm{Ni}_{\text {eq }}$ and $\mathrm{Cr}_{\mathrm{eq}}$ are the $\mathrm{Ni}$ and $\mathrm{Cr}$ equivalent (in wt pct), respectively, calculated using the present $\mathrm{Mn}, \mathrm{Si}, \mathrm{Ni}, \mathrm{C}$ content (in wt pet). The variation in the free energy change with annealing temperature shown in Figure 7 returns a $T_{\mathrm{o}}$ value of $\sim 602{ }^{\circ} \mathrm{C}$. In other words, $\alpha^{\prime}$-martensite reversion is expected to occur upon heating above $602{ }^{\circ} \mathrm{C}$. This calculated temperature is in agreement with our previous annealing study of bulk samples where $\alpha^{\prime}$-martensite reversion was observed at $600{ }^{\circ} \mathrm{C} \cdot{ }^{[23]}$ However, as mentioned above, reversion in the present thin foils was not observed upon heating below $800{ }^{\circ} \mathrm{C}$. This indicates that more driving force is required for $\alpha^{\prime}$-martensite reversion in thin foils compared to bulk samples. 


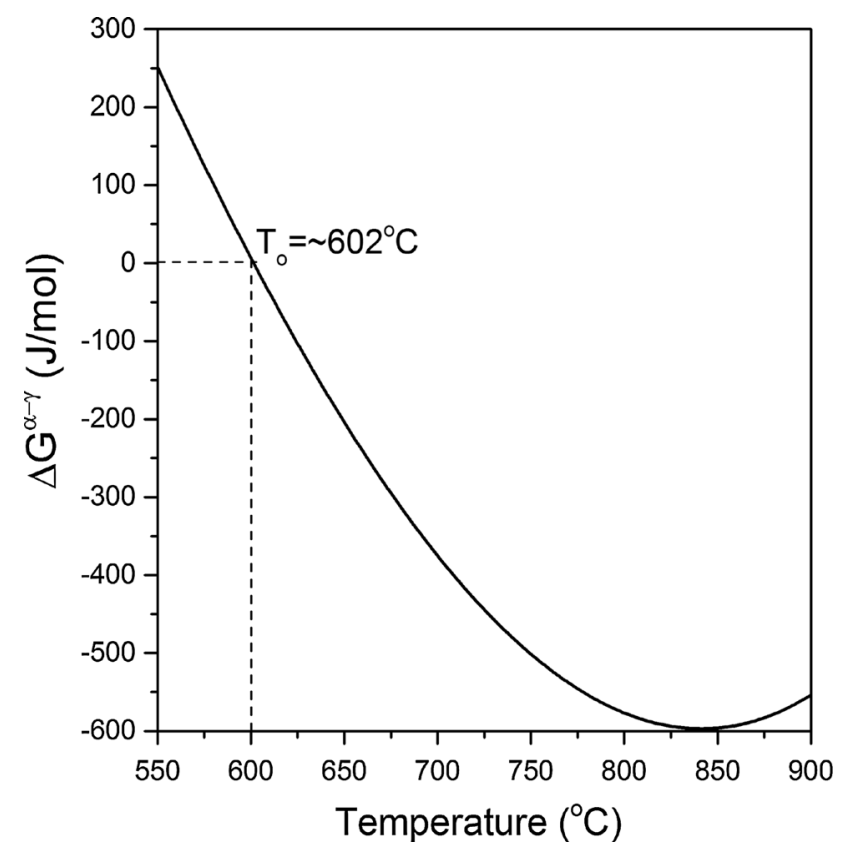

Fig. 7-Free energy change for $\alpha^{\prime}$-martensite to $\gamma$ reversion as a function of annealing temperature.

During electron back-scattering diffraction in situ heating of an Fe-1.5Mn-1.5Si-0.2C steel (processed by annealing at $780{ }^{\circ} \mathrm{C}$ and $400{ }^{\circ} \mathrm{C}$ for 300 seconds), Tomota et $a l .^{[51]}$ reported a reduction in the surface concentration of $\mathrm{Mn}$ and $\mathrm{C}$ measured using optical emission spectroscopy. This reduction was ascribed to the desorption of $\mathrm{Mn}$ atoms from the sample surface under high vacuum owing to its higher equilibrium vapor pressure along with decarburization at the sample surface. Both $\mathrm{Mn}$ and $\mathrm{C}$ increase the stability of $\gamma$ in comparison to $\alpha^{\prime}$-martensite. Thus, the decrease in their surface concentration leads to higher $\alpha^{\prime}$-martensite to $\gamma$ reversion temperatures. ${ }^{[51]}$ Similar reasoning can be used to explain the increase in $\alpha^{\prime}$-martensite reversion temperature in our in situ TEM heating experiments.

\section{CONCLUSIONS}

Based on the above in situ TEM observations, it can be concluded that:

(1) The reverse transformation on heating resulted in $\gamma$ inheriting the shape of the deformed $\varepsilon^{-}$and $\alpha^{\prime}$-martensite grains and exhibiting the $\mathrm{S}-\mathrm{N}$ and $\mathrm{K}-\mathrm{S}$ ORs, respectively. The $\varepsilon$ - and $\alpha^{\prime}$-martensite reversion occurred without any visible migration of the $\varepsilon$-martensite $/ \gamma$ and $\alpha^{\prime}$-martensite $/ \gamma$ interfaces. During the present in situ heating of thin foils, the reversion of $\varepsilon^{-}$and $\alpha^{\prime}$-martensite occurred at higher temperatures compared to bulk samples.

(2) The formation of fine twins in reverted $\gamma$ during recovery can be explained based on the growth of $\gamma$-ISFs derived from the faulted $\varepsilon$-martensite using a mechanism of gliding Shockley partial dislocations.

\section{ACKNOWLEDGMENTS}

The authors acknowledge the use of the JEOL 2200FS TEM and the assistance of Dr. Hongwei Liu at the Australian Microscopy \& Microanalysis Research Facility, University of Sydney. Prof. D. B. Santos of the Universidade Federal de Minas Gerais, Brazil is acknowledged for providing the source material. The financial support from the Engineering Materials Research Strength, UOW, is greatly appreciated.

\section{REFERENCES}

1. O. Grässel, L. Krüger, G. Frommeyer, and L.W. Meyer: Int. J. Plast., 2000, vol. 16, pp. 1391-1409.

2. U. Brüx, G. Frommeyer, O. Grässel, L.W. Meyer, and A. Weise: Steel Res. Int., 2002, vol. 73, pp. 294-98.

3. Y. Tomota, Y. Morioka, and W. Nakagawara: Acta Mater., 1998, vol. 46, pp. 1419-26.

4. Y. Lü, B. Hutchinson, D.A. Molodov, and G. Gottstein: Acta Mater., 2010, vol. 58, pp. 3079-90.

5. Z. Nishiyama: Martensitic Transformation, Academic Press, New York, 1978.

6. K. Tomimura, S. Takaki, and Y. Tokunaga: ISIJ Int., 1991, vol. 31, pp. 1431-37.

7. S.-J. Lee, Y.-M. Park, and Y.-K. Lee: Mater. Sci. Eng. A, 2009, vol. 515, pp. 32-37.

8. S. Rajasekhara, L.P. Karjalainen, A. Kyröläinen, and P.J. Ferreira: Mater. Sci. Eng. A, 2010, vol. 527, pp. 1986-96.

9. G. Kurdjumow and G. Sachs: Z Phys., 1930, vol. 64, pp. 325-43.

10. Y.K. Lee, H.C. Shin, D.S. Leem, J.Y. Choi, W. Jin, and C.S. Choi: Mater. Sci. Technol. Ser., 2003, vol. 19, pp. 393-98.

11. C. Celada-Casero, B.M. Huang, M.M. Aranda, J.R. Yang, and D.S. Martin: Mater. Charact., 2016, vol. 118, pp. 129-41.

12. H. Koohdar, M. Nili-Ahmadabadi, M. Habibi-Parsa, H.R. Jafarian, T. Bhattacharjee, and N. Tsuji: Metall. Mater. Trans. A, 2017, vol. 48A, pp. 5244-57.

13. K. Tominiura, Y. Kawauchi, S. Takaki, and Y. Tokunaga: Tetsu Hagane, 1991, vol. 77, pp. 1519-26.

14. J. Kowalska, W. Ratuszek, M. Witkowska, and A. ZielińskaLipiec: J. Alloy Compd., 2014, vol. 615, pp. S583-86.

15. A.A. Gazder, A.A. Saleh, M.J.B. Nancarrow, D.R.G. Mitchell, and E.V. Pereloma: Steel Res. Int., 2015, vol. 86, pp. 1204-14.

16. R.D.K. Misra, Z. Zhang, P.K.C. Venkatasurya, M.C. Somani, and L.P. Karjalainen: Mater. Sci. Eng. A, 2010, vol. 527, pp. 7779-92.

17. J. Han and Y.K. Lee: Acta Mater., 2014, vol. 67, pp. 354-61.

18. F. Mompiou, J. Wu, and W.Z. Zhang: Mater. Today, 2015, vol. 2, pp. S651-54.

19. J. Wu, J.M. Howe, and W.Z. Zhang: Acta Mater., 2011, vol. 59, pp. 3297-3303.

20. D. De Knijf, M.J. Santofimia, H. Shi, V. Bliznuk, C. Föjer, R. Petrov, and W. Xu: Acta Mater., 2015, vol. 90, pp. 161-68.

21. J. Singh and C.M. Wayman: Metallography, 1987, vol. 20, pp. 485-90.

22. H.B. Jiang, X.N. Luo, X.Y. Zhong, H.H. Zhou, C.Y. Wang, J. Shi, and H. Dong: J. Iron Steel Res. Int., 2017, vol. 24, pp. 1109-14.

23. S. Pramanik, A.A. Saleh, E.V. Pereloma, and A.A. Gazder: Mater. Charact., 2018, vol. 144, pp. 66-76.

24. D.R.G. Mitchell: Microsc. Res. Tech., 2008, vol. 71, pp. 588-93.

25. P.A. Stadelmann: Ultramicroscopy, 1987, vol. 21, pp. 131-45.

26. S.S.F. Dafé, F.L. Sicupira, F.C.S. Matos, N.S. Cruz, D.R. Moreira, and D.B. Santos: Mater. Res., 2013, vol. 16, pp. 1229-36. 
27. C. Hitzenberger, H.P. Karnthaler, and A. Korner: Acta Metall. Mater., 1988, vol. 36, pp. 2719-28.

28. L.C. Chang and H.K.D.H. Bhadeshia: Mater. Sci. Technol. Ser., 1995, vol. 11, pp. 874-82.

29. G. Krauss: Acta Metall. Mater., 1963, vol. 11, pp. 499-509.

30. P.T. Wakefield and M. Hatherly: Met. Sci., 1983, vol. 17, pp. 55-62.

31. J. Huber and M. Hatherly: Met. Sci., 1979, vol. 13, pp. 665-69.

32. K. Rajan: Metall. Trans. A, 1984, vol. 15, pp. 1335-38.

33. A.A. Saleh, D.W. Brown, E.V. Pereloma, B. Clausen, C.H.J. Davies, C.N. Tomé, and A.A. Gazder: Appl. Phys. Lett., 2015, vol. 106, pp. 171911-1-6.

34. A.A. Gazder, A.A. Saleh, A.G. Kostryzhev, and E.V. Pereloma: Mater. Today: Proc., 2015, vol. 2, pp. S647-50.

35. S. Pramanik, A.A. Gazder, A.A. Saleh, and E.V. Pereloma: Mater. Sci. Eng. A, 2018, vol. 731, pp. 506-19.

36. G.B. Olson and M. Cohen: Metall. Trans., 1975, vol. 6, pp. 791-95.

37. D.A. Porter, K.E. Easterling, and M. Sherif: Phase Transformations in Metals and Alloys, 3rd ed., Taylor and Francis, Boca Raton, FL, 2009.

38. N. Nakada, T. Tsuchiyama, S. Takaki, D. Ponge, and D. Raabe: ISIJ Int., 2013, vol. 53, pp. 2275-77.

39. R. Abbaschian, L. Abbaschian, and R.E. Reed-Hill: Physical Metallurgy Principles, 4th ed., Cengage Learning, Connecticut, CT, 2008.
40. F.S. Buffington, K. Hirano, and M. Cohen: Acta Metall. Mater., 1961, vol. 9, pp. 434-39.

41. H. Bibring, G. Lenior, and F. Sebilieau: Rev. Metall., 1959, vol. 56, p. 279.

42. J.A. Klostermann and W.G. Burgers: Acta Metall. Mater., 1964, vol. 12, pp. 355-60.

43. J. Pak, D.W. Suh, and H.K.D.H. Bhadeshia: Metall. Mater. Trans. A, 2012, vol. 43A, pp. 4520-24.

44. B.B. He, M.X. Huang, A.H.W. Ngan, and S. Van Der Zwaag: Metall. Mater. Trans. A, 2014, vol. 45A, pp. 4875-81.

45. J.D. Escobar, G.A. Faria, L. Wu, J.P. Oliveira, P.R. Mei, and A.J. Ramirez: Acta Mater., 2017, vol. 138, pp. 92-99.

46. A. Bojack, L. Zhao, P.F. Morris, and J. Sietsma: Mater. Charact., 2012, vol. 71, pp. 77-86.

47. S. Kajiwara: Trans. Jpn. Int. Met., 1985, vol. 26, pp. 595-96.

48. D.P. Escobar, S.S.F. Dafé, and D.B. Santos: J. Mater. Res. Technol., 2015, vol. 4, pp. 162-70.

49. A. Gilbert and W.S. Owen: Acta Metall. Mater., 1962, vol. 10, pp. $45-54$.

50. M.C. Somani, P. Juntunen, L.P. Karjalainen, R.D.K. Misra, and A. Kyröläinen: Metall. Mater. Trans. A, 2009, vol. 40A, pp. 729-44.

51. Y. Tomota, N. Sekido, S. Harjo, T. Kawasaki, W. Gong, and A. Taniyama: ISIJ Int., 2017, vol. 57, pp. 2240-47. 